\title{
Corporate Despotism: Management in Anarchy or Anarchy in Management
}

\section{Uzoma E. Osita-Ejikeme}

Department of Management, University of Port Harcourt, Nigeria.

DOI - http://doi.org/10.37502/IJSMR.2021.4712

\begin{abstract}
This study adds to existing literature on Corporate Despotism. Specifically, it examines which of the two (Management in Anarchy or Anarchy in Management) is an outcome of Corporate Despotism. It uses the case of former Diamond Bank Plc. to elucidate the discourse. Consequences of corporate despotism leading to anarchy range from job dissatisfaction to low performance and may lead to the failure of the organisation at large. Accountability mechanisms should be introduced and reinforced for the eradication of despotic leadership at all management levels.
\end{abstract}

Keywords: Corporate Despotism, Anarchy, Management.

\section{Introduction}

Most people believe that organisations operate in a complex and rapidly changing world. As a result, various factions may develop within the organisation, with varying degrees of benefit and risk to the organisation. It is possible for individuals to have complete control over their own lives. It is widely thought to be a case of corporate despotism whenever this happens. An organisation where one person or a group of people have total power over the organisation is referred to as corporate despotism. Following the recent outburst of destructive leadership behaviour, people have begun to notice (Tepper, 2001). Theories increasingly have concentrated on the impact of Destructive Leadership (in other words, bad leadership) on company performance over time (Naseer et al., 2016). This behaviour is in contravention of company policies and guidelines. The organisation's overall performance suffers as a result. More time in the workplace has increased the level of workplace negativity, including workplace bullying, embezzlement, and other beneath-the-belt behaviours. Selfishness, unfairness, theft, kickbacks, and such are all rising, as is negative behaviour such as hogging breaks, accepting bribes, theft, and so on. We will not go into details about the numerous dangers of dysfunctional behaviour, as it would be too tedious. If a group of people behave in this manner, anarchy can result. Would we say that despotism causes management in anarchy or that despotism causes anarchy in management? This premise underlies this work.

\section{Meaning of Despotism}


A form of government in which a single authority wields absolute political power is known as despotism. A fundamental form of despotism is one in which one person holds all power and authority, and everyone else is subject to that person's dictates. Despotism is an arbitrary rule imposed by a single person who instils fear in a population by monopolizing power and wielding it without restraint (Kets de Vries, 2004). Despots interfere with the rule of law, fundamental human rights, achievement, and advancement (Kets de Vries, 2004).

Montesquieu documents despotism's persistence in his book “The Spirit of the Laws" (1748), as illustrated in Sullivan (2017). Even those who are fortunate enough to live outside of a despotic government's borders can be victims of despotic practices, even if they aren't suffering under the control of an oppressive regime. To show the ill effects of despotism, Montesquieu says that exposing it must remain a major priority in social and political activities.

\section{Corporate Despotism}

It is called a corporate despotism when an individual or a small group of people rules over an organisation with absolute political power. It is a state in which one person or a small group of people have power and authority over an organisation, and the needs of others are disregarded. The people or group that control and influence what occurs within the organisation are referred to as despots. Affected by a person in this way is a common occurrence.

Workers who become despotic managers require, supervise, and respond selfishly to the demands and concerns of their subordinates, who must pledge their full and complete devotion and consent (Schilling, 2009). Managers with despotic tendencies are tainted morally, and lack ethical standards (De Hoogh \& Den Hartog, 2008). To exploit their followers, they limit the involvement of their members in the decision-making and control processes, and therefore make unfair decisions (Aronson, 2001). It is due to the level of trustworthiness and moral values that despotic managers have that their followers have less of a chance of demonstrating their abilities at work, questioning workplace citizenship norms, and using their creative potential.

The despotic manager has unreasonable expectations of his or her staff, commands rather than encourages, is unconcerned with staff well-being, does not facilitate teamwork, and expects their staff to do their duties without question (Schilling, 2009). It puts the focus on the power dynamic in which subordinates are constantly under the heel of a domineering superior. Based on the study, despots run on their own bias, have fascistic moral standards, and are corrupt (De Hoogh \& Den Hartog, 2008).

Aggressive and domineering managers like this, as described by De Hoogh and Den Hartog (2008), mistreat and exploit their subordinates. Schilling (2009) says that despotic managers want their subordinates to be more submissive, and also want them to use subordinate workers and methods to exploit and manipulate subsidiary firms for their own personal gain, not to mention the occupants' personal desires and needs. Those who wield despotic power are hostile to the organisation's legitimacy. There is a direct connection between corrupt behaviour and bullying and immorality (Einarsen et al., 2007). Manager anonymity, immorality, and dishonesty are all present. They act dishonestly and put their own interests first, which distorts their subordinates' work by making subordinates believe that their work is unimportant because they will not be rewarded for their accomplishments (Schyns \& Schilling, 2013). Trustworthy 
managers have the ability to promote enthusiasm, trust, loyalty, and organisational citizenship in their employees (Tepper, 2000; De Hoogh \& Den Hartog, 2008). Despite mounting evidence, despotic work culture is bad for workers.

\section{Anarchy and Management}

The origins of anarchy go back to the Greek word anarchos, which means "not having a leader". While this concept seems to promote chaos and civil unrest, it has become synonymous with self-government and community consensus (Kenton, 2021). The word "anarchism" was defined by the Oxford Dictionaries as "the doctrine advocating abolition of government and a social order based on voluntary co-operation, without recourse to force or compulsion." The definition of anarchy is characterized by the absence of a central authority, as well as the absence of rulers and centralized authority. The term anarchy was defined by the late-20th-century sociologist, Walter J. Waltz (1979), cited by Cerny and Prichard (2017), according to which it means order without an orderer and organisational effects in the absence of formal organisation. The definition of anarchy is that it describes a state of affairs where there is disorder and chaos, as well as the absence of governance. It is time for the authoritarian to answer the anarchist's call, which challenges those in positions of power to justify their claims to power. In order to defend their positions, the authoritarian must prove that their systems are just (Chomsky, 2014).

Management is all about forecasting and planning, and then organisation, command, coordination, and control. It is essential to look into the future and devise a strategy if you want to make an impact on the world. It is essential to build a dual structure of both material and human elements. What it means to command is maintaining activity among the personnel. When you coordinate your activities and efforts, you bring everything together, unify everything, and harmonize everything. In order to control something, we must set up rules and a set of orders and make sure everything is carried out according to them (Fayol, 1916, in Kaehler \& Grundei, 2019). The quote about management is known as the art of getting things done through people, according to Mary Parker Follett. Management is a universal human activity in both personal, social, and political settings, as well as in work environments (Boddy, 2017). Resources must be organised, directed, and controlled in order to perform well (Schermerhorn, 2005). Management is defined as getting things done by directing or assisting others in whatever manner possible. This can be done on both the people and information planes (leading and linking) or the controlling and communicating (controlling and communicating) (Mintzberg, 2009). A firm management practice is the use of efficient and effective practices to efficiently and effectively pursue organisational goals, which are accomplished by bringing people together to combine their tasks using planning, organising, leading, and controlling of the organisation's resources (Kinicki \& Williams, 2018). Despite nearly a century having passed, Henri Fayol's advice to managers has stood the test of time. In addition, it has been further developed by recent authors (Cole \& Kelly, 2015).

Management must have a hierarchy. In all but the smallest businesses and organisations, businesses and corporations are organised hierarchically. In a nutshell, whoever says management, hierarchy comes to mind (Diefenbach, 2013). Board members, CEOs, and managers are the power elite. They sit at the top of the managerial hierarchy, and they use their 
power to shape people's values and create a unified vision (Klikauer \& Campbell, 2020). Anarchy is focused on networks, rather than structures (Klikauer \& Campbell, 2020).

\section{Management in Anarchy or Anarchy in Management}

While the words "anarchy" and "management" are commonly associated with rejecting one and embracing the other. Contrary to popular belief, there is no actual contradiction between studying management and studying radical social and political thought. The number of new organisational models continues to increase, whether due to anarchism, syndicalism, ecological activism, cooperative enterprises, libertarian communism, self-help groups, or feminism (Gibson Burrell, 1992 in Swann \& Stoborod, 2014).

Many CEOs are adept at using double meanings to portray themselves as wise men, while management as a whole thrives on the power that comes with holding a position (Magretta, 2012) and, of course, workers who are forced to accept the authority, power, and authority of managerial offices and managerial leaders. To the extent that Anarchism indicates the insignificant role of government and other centralized power, it also symbolizes freedom (Klikauer \& Campbell, 2020).

Management in Anarchy results in a state of confusion. When in anarchy, there is no management and therefore, confusion results. No obvious solution is in sight. No end goals have been defined. He follows everybody else's lead. Managers will not be fully committed to the company or put forth their best effort. Many people have their own agendas or personal interests to pursue, not necessarily ones that serve the interests of the organisation. In other words, this reveals just how confused the employees are because they have no clear job roles, they have no proper supervision, and they don't have a scalar chain.

In contrast, some corporate leaders, managers, or CEOs commit acts outside of the law when they exercise control and management over their respective organisations. This is reffered to as Anarchy in management. They are not organised, and their aim is only to take advantage of others for their own gain. These individuals in charge of the organisation are disregarding or failing to conform to the organisation's established practices and customs. Anarchy can be seen in management where there is one or a small number of powerful individuals or just one who monopolizes control.

\section{Corporate Despotism: Anarchy in Management}

Coming back to the issue of corporate despotism, would we say that when such happens within the organisation, there is anarchy in management?

Well, if a certain person or a closely knitted group of persons exert absolute power on others, one would say there is anarchy in management. Corporate despotism results in anarchy within the management. These set of persons do not adhere to the laid down rules and guidelines within the organisation. In extreme cases, they become the law.

\section{Sole Proprietorship or One-man Business as an Example}

A Sole Proprietorship firm, sometimes known as a "one-man business", is a form of business created and maintained by one person with the sole purpose of meeting a need and generating profit. This individual is the company's financer, controller, and manager. He is the 
one who makes all the decisions and reaps the advantages. However, the individual takes all of the risk alone. The sole proprietor does not have to report to anybody, does not have to submit an annual report, and does not have to disclose audited financial statements for anyone. The business owner makes all of the decisions and conducts the company in his or her own manner, and may lack the managerial skills needed to manage the business.

\section{A Case Study of Diamond Bank Nigeria}

Diamond Bank Plc. was founded in 1990. In March of 1991, the bank that Dr. Dozie and his wife Chinyere envisioned, provided financial services to Nigeria, Africa, and the rest of the world when it opened its doors Benedict (2005). The bank ran the gamut from lending and equipment leasing to electronic and internet banking, Western Union money transfers, investment banking, money market trading, and foreign exchange (Bloomber, 2021). The bank was listed on the Nigerian Stock Exchange in 2005, becoming a public limited company in the process. Due to its advanced financial technology and exceptional customer service, Diamond Bank was one of Nigeria's most reputable financial institutions. The bank experienced a significant increase in the amount of its non-performing loans, and on April 1, 2019, it merged with Access Bank, which was led by CEO Uzoma Dozie (a qualified Chemist and MBA holder, and the first son of Dr. Pascal Dozie). The abrupt decline of retail banking, and its move to offshore banking, show how bad corporate governance can lead to disaster.

Non-Performing Loans (NPLs) and board disharmony created serious problems for the company, including chronic breaches of governance rules in the oil sector, which caused massive Non-Performing Loans (NPLs), and disruptive meetings, which caused questionable decisions, according to Chijoke (2018). The repeated insistence on making final decisions in critical situations despite the implications for the company was linked to the "ownership" mentality, and in turn increased board politics and hastened the company's demise (Chijoke, 2018). The bank's financial statements indicate that management allowed the firm to become highly vulnerable to low cost of funds while making increasingly risky loans, resulting in an NPL of $12.6 \%$ versus the industry benchmark of 5\%, and significant write-offs.

Board politics descended into mutual suspicion and an entrenched division of loyalties based on an employee's individual interests, according to one of the company's senior management. Fear reigned, and morale was at an all-time low. This CEO once made the statement that "evil people" needed to be removed from the company. For that reason, you are at a higher risk if someone close to him dislikes you, or if he himself feels you have done something wrong. It was once the case that competent workers were being replaced at will. Instead of promoting the more experienced, unskilled individuals to positions of leadership, he promoted those with less experience to be leaders. On top of that, he punished those who showed courage in the bank and asked objective analysis instead. He also fired all of the bank's strategic department personnel, including those who had planned a send-off for the department head, whom he had fired beforehand (Chijioke, 2018). It is difficult to find anyone who had a positive experience working at the bank due to his management style (Chijioke, 2018). The chief executive attempted to remove four directors from the board of directors, as a means of undermining the non-executive directors' independence. The resignations were offered with no foundation, and it appearsed that the acceptance of these resignations were done in bad faith. These resignations could not hold, and the acceptance of these resignations was meaningless. However, let's take 
a look at where the bank has ended up. If you run an institution like this, you should not expect better results.

Moody's claims that bad leadership, ineffective risk management, and board issues contributed to the failure of Diamond Bank. Some of the reasons cited for the Board's failure included a lack of independence and frequent turnover among board members (Ekekwe, 2019). Several bad decisions made by the bank's leadership lead to a decrease in profits and eventually, a loss in 2017. The bank had a net loss of N9 billion in 2017, after making profits of N5 billion in 2016. Several board members had lost confidence in Uzoma Dozie (Adeleke, 2019).

In 2018, Proshare issued a public letter authored by Carlyle Group's Carlyle Sub-Saharan Africa Fund (CSSAF) and DBN Holdings, the bank's largest shareholder, expressing their desire to have Dozie removed as the bank's CEO. Bickerstheth wrote in the letter that CSSAF DBN Holdings, a large shareholder, demanded that management, especially the CEO, be fired immediately, but the Board, rather than taking a more extreme approach, wanted to lessen the impact on the business and allow the Board to find new leadership. After numerous meetings, the CEO of the bank, who was also a major shareholder in the company, announced his resignation on January 3, 2019, but did not send in a letter to verify the verbal notice. The Dozie family owned 5\% of the bank and 9\% due to their investment firm, Kunoch Ltd. (14\% in total). The Carlyle Fund owned 18\% of the stock (Adeleke, 2019). Moody's states that the Diamond bank board was unable to oversee the bank's management team.

It was blatant nepotism. The CEO as at when the bank merged was the son to the founder, and he promoted inexperienced people to positions of leadership when the bank. Nepotism is a concept related to organisational politics that is defined as the interplay of politics that results in someone being appointed to a position based on familial ties (Bute, 2011). Moody's assessment found that Diamond Bank's new board members generally lacked sufficient knowledge of the bank. More of the state Diamond bank can be seen in Chijioke's (2018) and Adeleke's (2019) articles.

\section{Consequences}

Where an organisation has despotic leaders resulting in a state of anarchy within the management, it cannot be left without its consequences. Some consequences of the effect of despotic anarchism within the management are as follows:

Job Dissatisfaction: Corrupt, despotic managers negatively impact the performance, organisational citizenship, and creativity of their subordinates (Naseer et al., 2016). Leadership behaviour can have serious consequences that extend beyond subordinates, including company productivity, customers, employee families, and even the entire community. People who engage in this kind of behaviour are more likely to have a host of undesirable outcomes, such as a lower level of job satisfaction, commitment to the organisation, and productivity, as well as a heightened amount of emotional exhaustion, intent to leave, work-family conflict, and psychological distress (Aasland et al., 2010; Hershcovis and Rafferty, 2012; Schyns and Schilling, 2013).

Employee Turnover: As companies with management that is highly despotic have a high turnover of employees. Leaving an organisation has both short-term and long-term financial 
implications for both the employee and the company (Lee et al., 2004). Kleinman (2013) noted that the employee's intention to leave depends, a great deal, on the behaviour of the employer. Job Disengagement: Individuals who are presented with coercive leadership behaviour, such as despotic rule, direct all of their energy and attention to handling the situation, depleting their own energy resources in the process. Workers who have been harmed by unethical or selfserving leadership will disengage from their jobs (Jabeen \& Rahim, 2020).

Job Insecurity: Given the criticality of job insecurity, some studies have found that poor and unethical treatment of abusive supervisors negatively affects perceptions of job security, and that abusive supervisors negatively affect perceptions of job security (Tepper, 2000). Future uncertainty and involuntary major job changes from their employer are considered as indicators of a perceived level of job insecurity, according to Hui and Lee (2000). Workplace insecurity is exemplified by a high level of uncertainty and threat, according to Cheng and Chan (2008). According to Sverke, Hellgren, and Näswall (2002), employees who are worried about losing their jobs do not necessarily mean they will be laid off. More precisely, job insecurity refers to the expectation of a stressful event and the consequent uncertainty about one's job security, where it is feared that the nature and future of one's job are both in jeopardy.

Low Performance: Workers may choose to respond to despotic managers with attitudes and behaviours that could endanger the manager and the organisation (such as not taking responsibility, slowing work, etc.). Thus, when employees are under the control of a despotic manager, their creative behaviour decreases, and their performance also declines. Decreased employee performance might be due to a despotic manager's oppressive behaviour, which weakens their motivational effect. Workers' performance will follow the principle of social exchange and will lead to the failure of the organisation unless where a despotic leader is at the helm. It is critical to workers' performance that the attitudes and approach of management are at the core of employees' interest in the work outcomes (Youssef \& Luthans, 2007). Ultimately, the most important variable in the performance of subordinates is their supervisor's leadership behaviour, which motivates those (Pinto et al., 2014).

Low Motivation or Morale: Often, followers are motivated to devote mental, emotional, and physical resources in responding to leaders who are angry with them (Grande \& Gabriel, 2015, in Nauman et al., 2018). Changes can be requested by employees who have the authority to make them, and employees who make the changes are expected to speak with those who requested them (i.e. Despotic managers). In the view of Ferguson et al. (2009), unethical leadership starves employees of their own self-reserves (e.g. optimism, attention, willpower, esteem), making them easier to control. When employees are victimized or vulnerable due to an unethical manager, their own personal resources (vitality, self-esteem, etc.) are lowered or diminished (Thau, Aquino, \& Poortvliet, 2007).

Deviant Behaviours: As stated by Avolio (2007), managers who exercise despotic control are unsympathetic and have weak moral values, which make it impossible for them to motivate subordinates to meet personal and/or organisational objectives. As a result, employees' ability to maintain appropriate behaviour is diminished, which in turn motivates them to engage in deviant behaviour such as ignoring organisational goals, stealing resources, and encouraging other employees to do the same (De Hoogh \& Den Hartog, 2008).

Knowledge Hoarding: Schyns and Schilling (2013) state that negative behaviours or events have a greater impact on a person's behaviour and actions in social interactions. Managers' 
self-centeredness results in employees being reluctant to open up to them, because it means that the manager will reject their ideas and suggestions, and thus their relationship will become strained. As a result, workers elect to limit them in order to shield themselves from the manager's possible retribution (Liao et al., 2019).

Counterproductive Work Behaviours: According to Nauman and Fatima (2018), emotional wear and tear is brought on by a despotic manager. The social exchange theory suggests that employees' behaviours are dependent on the treatment they receive from their immediate and managerial managers, as proposed by Cropanzano and Mitchell (2005). People have a natural tendency to respond to what they are experiencing. Taking revenge in the form of counterproductive behaviour is another way to express discontent. An organisation's worst enemy is the behaviour of its own employees, also known as counterproductive work behaviours (Sackett et al., 2006). From earlier discussions, this maladaptive behaviour may include activities such as fraud, theft, bullying, and more.

Despite employees' knowledge of the detrimental effects of despotic managers, Offerman (2004) argues that employees put up with them out of personal and professional goals such as advancing in the company and advancing on their own personal agendas (Kellerman, 2004).

\section{Conclusion}

Honest and trustworthy managers are more likely to develop followers' optimism, trust, loyalty and organisational citizenship behaviour. Corporate despotism is without doubt disadvantageous to any organisation. Management is a hierarchy with laid down rules, principles and guidelines. When a certain individual or tightly knitted set of individuals decide to take up excessive power upon them deciding how work is been done within a firm, it can result in a state of anarchy and at such is detrimental to the success of the organisation. The employees work for the employers for the greater part of their lives, not because they enjoy it nor have control over their work, but because they see it as their only means of livelihood. Management in anarchy is an outcome of anarchy in management. Where an individual exercises absolute power within the management cadre, and such person does that without adhering to laid down rules and guidelines, every other person would have no direction. There would be disorganisation, role ambiguity, confusion and stress. This will also have an effect on the employees or subordinates. Consequences of corporate despotism leading to anarchy range from job dissatisfaction to low performance and may lead to the failure of the organisation at large.

\section{Theoretical Implications}

This study's existing literature furthers and broadens the existing knowledge on destructive leadership. Those who are bullied by their supervisors suffer from despotic supervision. To remove despotic leaders, managers and organisations must take appropriate steps. Also, a fullfledged accountability framework must be implemented at all levels of management in order to stop despotic leadership, and in such an undertaking, to root out anarchistic leadership. 


\section{References}

1) Aasland, M. S., Skogstad, A., Notelaers, G., Nielsen, M. B., and Einarsen, S. (2010). The prevalence of destructive leadership behaviour. British Journal of Management. 21, 438-452.

2) Adeleke, D. (2019, May 9). A new Moody's report reveals exactly how Diamond Bank failed, Business Insider: Africa, https://africa.businessinsider.com/finance/a-newmoodys-report-reveals-exactly-how-diamond-bank-failed/n1zb3s5

3) Adigüzel, Z. (2019). Examination of the effects of despotic leadership and strategic human resources management on the employees in the business world, Journal of management and economics research, 17(1), 143-162, DOI: http://dx.doi.org/10.11611/yead.446409

4) Aronson, E. (2001). Integrating leadership styles and ethical perspectives, Canadian Journal of Administrative Sciences, 18, 244-256.

5) Avolio, B. J. (2007). Promoting more integrative strategies for leadership theorybuilding. American Psychologist, 62(1), 25.

6) Blooomberg (2021). Diamond Bank PLC, Retrieved $2^{\text {nd }}$ August, 2021 from https://www.bloomberg.com/profile/company/DIAMONDBNK:NL

7) Boddy, D. (2017). Management - An Introduction (7th edition). Harlow: Pearson Education.

8) Bute, M. (2011). The effects of nepotism and favoritism on employee behaviours and human resources practices: a research on Turkish public banks. Todade's Review of Public Administration, 5(1), 185-208.

9) Cerny, P. G., \& Prichard, A. (2017). The new anarchy: Globalisation and fragmentation in world politics. Journal of International Political Theory, 13(3), 378-394. https://doi.org/10.1177/1755088217713765

10) Cheng, G.H., \& Chan, D. (2008). Who suffers more from job insecurity? A MetaAnalytic review. Applied Psychology, 57, 272-303; DOI:10.1111/J.14640597.2007.00312.X

11) Chijoke, N. (2018, December 24). How intrigues, lapses, losses caused Diamond Bank's fall, The Guardian Business: Nigeria Edition, https://guardian.ng/businessservices/how-intrigues-lapses-losses-caused-diamond-banks-fall/

12) Chomsky, N. (2014). Preface to Antologija Anarzma, Chomsky on Anarchism, ed. Barry Pateman, Oakland: AK Press.

13) Cole, G.A. \& Kelly, P. (2015). Management - Theory and Practice (8th edition). Andover: Cengage Learning EMEA.

14) Cropanzano, R. \& Mitchell, M.S. (2005). Social exchange theory: an interdisciplinary review, Journal of Management, 31(6), 874-900.

15) De Hoogh, A. H. \& Den Hartog, D. N. (2008). Ethical and despotic leadership, relationships with leader's social responsibility, top management team effectiveness and subordinates' optimism: A multi-method study, The Leadership Quarterly, 19, 297-311.

16) De Hoogh, A. H., \& Den Hartog, D. N. (2008). Ethical and despotic leadership, relationships with leader's social responsibility, top management team effectiveness 
and subordinates' optimism: A multi-method study. The Leadership Quarterly, 19(3), 297-311.

17) Diefenbach, T. (2013). Hierarchy and Organisation, London: Routledge.

18) Einarsen, S., Aasland, M. S. \& Skogstad, A. (2007). Destructive Leadership Behaviour: A Definition and Conceptual Model. The Leadership Quarterly, 18, 207-216.

19) Ekekwe, N. (2019, May 12). Three Reasons Why Diamond Bank Failed - Moody's, Tekedia, https://www.tekedia.com/three-reasons-why-diamond-bank-failed-moodys/

20) Hershcovis, M. S., and Rafferty, A. E. (2012). Predicting abusive supervision. Contemp. Occup. Health Psychol. Glob. Perspect. Res. Pract. 2, 92-108. doi: 10.1002/9781119942849.ch6

21) Hui, C., \& Lee, C. (2000). Moderating Effects of Organisation-Based Self-Esteem on Organisational Uncertainty: Employee Response Relationships. Journal of Management, 26, 215 - 232; DOI:10.1177/014920630002600203

22) Jabeen, R. \& Rahim, N. (2020). Mediating Role of Perception of Job Insecurity on the Relationship between Despotic Leadership and Work Engagement: Pakistani Perspective, Review of Economics and Development Studies, 6 (2), 277 - 288; DOI: 10.47067/reads.v6i2.205

23) Kaehler, B. \& Grundei, J. (2019). HR Governance: A Theoretical Introduction, Springer, http://dx.doi.org/10.1007/978-3-319-94526-2

24) Kellerman, B. (2004). Bad leadership: What it is, how it happens, why it matters, Harvard Business Press.

25) Kets de Vries, M.F.R. (2004).The spirit of despotism: Understanding the tyrant within,' INSEAD Working Paper Series, 2004/17/Ent.

26) Kinicki, A. \& Williams, B.K. (2018). Management - A Practical Introduction (8th edition); New York: McGraw-Hill.

27) Kleinman, C. (2013). The relationship between managerial leadership behaviours and staff nurse retention. Hospital Topics, 82(4), 2-9.

28) Klikauer, T. \& Campbell, N. (2020, July 13). Marx \& Philosophy Review of Books [Review of the book Anarchism, Organisation and Management: Critical Perspectives for Students, by M. Parker, K. Stoborod \& T. Swann]. Marx Philosophy Society, Retrieved from https://marxandphilosophy.org.uk/reviews/18172_anarchismorganisation-and-management-critical-perspectives-for-students-by-martin-parkerkonstantin-stoborod-and-thomas-swann-eds-reviewed-by-thomas-klikauer-nadinecampbell/

29) Liao, S., Zhou, X., Guo, Z., \& Li, Z. (2019) How Does Leader Narcissism Influence Employee Voice: The Attribution of Leader Impression Management and LeaderMember Exchange. International Journal of Environmental Research and Public Health, 16(10), 1819, doi:10.3390/ijerph16101819

30) Magretta, J. (2012). What Management Is: How it Works and Why It's Everyone's Business, London: Profile.

31) Mintzberg, H. (2009). Managing, San Francisco: Berret-Koehler Publishers.

32) Naseer, S., Raja, U., Syed, F., Donia, M. B., and Darr, W. (2016). Perils of being close to a bad leader in a bad environment: exploring the combined effects of despotic 
leadership, leader member exchange, and perceived organisational politics on behaviours. Leadersh. Q. 27, 14-33. doi: 10.1016/j.leaqua.2015.09.005

33) Nauman, S., \& Fatima, T. (2018). Does despotic leadership harm employee family life: exploring the effects of emotional exhaustion and anxiety. Frontiers in psychology, 9, 601.

34) Offermann, L. (2004). When Followers Become Toxic, Harvard Business Review, 84(1), 54-60.

35) Pinto, J. K., Dawood, S., \& Pinto, M. B. (2014). Project management and

36) burnout: Implications of the Demand-Control-Support model on projectbased work.

International Journal of Project Management, 32(4), 578-589. doi: 10.1016/j.ijproman.2013.09.003

37) Proshare (2018, December 10). What Does It Mean That Independent Directors Accuse Diamond Bank Of Corporate Governance Issues? Proshare Intelligence Investing, Retrieved $2^{\text {nd }}$ August, 2021 from https://www.proshareng.com/news/Frauds--Scandals/What-Does-It-Mean-That-Independent-Direc/43104

38) Sackett, P. R., Berry, C. M., Wiemann, S. A. \& Laczo, R. M. (2006). Citizenship and Counterproductive Behaviour: Clarifying Relations between the Two Domains. Human Performance, 19, 441-464. 64.

39) Schermerhorn, J.R. Jr. (2005). Management (8th edition); Hoboken: John Wiley \& Sons.

40) Schilling, J. (2009). From ineffectiveness to destruction: A qualitative study on the meaning of negative leadership, Leadership, 5, 102-128.

41) Schyns, B., \& Schilling, J. (2013). How bad are the effects of bad leaders? A metaanalysis of destructive leadership and its outcomes. The Leadership Quarterly, 24(1), 138-158.

42) Sullivan, V.B. (2017). Despotism is all around us: the warnings of Montesquieu, Retrieved 2nd August, 2021 from https://aeon.co/ideas/despotism-is-all-around-us-thewarnings-of-montesquieu

43) Sverke, M., Hellgren, J., \& Näswall, K. (2002). No security: a meta-analysis and review of job insecurity and its consequences. Journal of occupational health psychology, 73 , 242-64; DOI:10.1037/1076-8998.7.3.242

44) Swann, T. \& Stoborod, K. (2014). Did you hear the one about the anarchist manager? Ephemera: theory \& politics in organisation, Retrieved 2nd August, 2021 from http://www.ephemerajournal.org/contribution/did-you-hear-one-about-anarchistmanager

45) Tepper, B. J. (2000). Consequences of abusive supervision, Academy of Management Journal, 43, 178-191.

46) Tepper, B.J. (2001) Health consequences of organisational injustice: Tests of main and interactive effects. Organisational Behaviour and Human Decision Processes, 86, 197 215; https://doi.org/10.1006/obhd.2001.2951

47) Thau, S., Bennett, R. J., Mitchell, M. S., \& Marrs, M. B. (2009). How management style moderates the relationship between abusive supervision and workplace deviance: An uncertainty management theory perspective. Organisational Behaviour and Human Decision Processes, 108(1), 79-92. 
48) Waltz, KN (1979). Theory of International Politics. Reading, MA: Addison-Wesley.

49) Youssef, C. M., \& Luthans, F. (2007). Positive organisational behaviour in the workplace: The impact of hope, optimism, and resilience. Journal of Management, 33(5), 774-800. https://doi.org/10.1177/0149206307305562

50) Zellars, K. L., Tepper, B. J., \& Duffy, M. K. (2002). Abusive supervision and subordinates' organisational citizenship behaviour. Journal of Applied Psychology, 87(6), 1068. 